\title{
Anne-Marie Baron, 'La Comédie humaine» oeuvre autobioromanesque ou autofiction?
}

\section{Marco Stupazzoni}

\section{(2) OpenEdition}

1 Journals

\section{Edizione digitale}

URL: http://journals.openedition.org/studifrancesi/36392

DOI: $10.4000 /$ studifrancesi.36392

ISSN: 2421-5856

\section{Editore}

Rosenberg \& Sellier

\section{Edizione cartacea}

Data di pubblicazione: 1 juillet 2005

Paginazione: 184

ISSN: 0039-2944

\section{Notizia bibliografica digitale}

Marco Stupazzoni, «Anne-Marie Baron, 'La Comédie humaine» oeuvre autobioromanesque ou

autofiction?», Studi Francesi [Online], 145 (XLIX | I) | 2005, online dal 30 novembre 2015, consultato il 20 avril 2021. URL: http://journals.openedition.org/studifrancesi/36392 ; DOI: https://doi.org/10.4000/ studifrancesi.36392

Questo documento è stato generato automaticamente il 20 avril 2021.

\section{(c) (1)}

Studi Francesi è distribuita con Licenza Creative Commons Attribuzione - Non commerciale - Non opere derivate 4.0 Internazionale. 


\title{
Anne-Marie Baron, 'La Comédie humaine» oeuvre autobioromanesque ou autofiction?
}

\author{
Marco Stupazzoni
}

\section{NOTIZIA}

ANNE-MARIE BARON, 'La Comédie humaine» oeuvre autobioromanesque ou autofiction?, «L'École des lettres - second cycle», 94e année, $\mathrm{n}^{\circ} 12$, mai 2003, pp. 47-55.

1 Evocati in forme diverse e in modo discontinuo nella corrispondenza, nelle prefazioni e nei romanzi, i ricordi e le ossessioni familiari di Balzac sono alla base di una costruzione finzionale in cui le immagini e i fantasmi autobiografici alimentano la scrittura narrativa.

2 A.-M. Baron interpreta La Comédie humaine come «une oeuvre autobioromanesque, dans laquelle on retrouve presque partout la même configuration, le même mythe personnel, les mêmes fantasmes de persécution» (p. 55).

3 Ciò che importa, per comprendere l'universo balzachiano, non è tanto la ricostruzione più o meno fedele di fatti biografici, ma essenzialmente il modo in cui lo scrittore ha vissuto quegli eventi ricreati successivamente attraverso le forme del ricordo e dell'immaginazione (di particolare importanza è, ad esempio, il tema dell'allattamento che attraversa in maniera ossessiva tutta la Comédie).

4 Tuttavia, per «transmuer de telles obsessions - conclude l'A. -, il a fallu toute l'alchimie de la création balzacienne; elle a transformé ce passé en une véritable construction mentale qui, de proche en proche, a ensuite servi comme point de départ à l'activité romanesque» (ibid.). 